\title{
Pulsed-field gel electrophoresis, virulence determinants and antimicrobial susceptibility profiles of type la group B streptococci isolated from humans in Brazil
}

\author{
Ana Beatriz de A Corrêa, Ivi Cristina M de Oliveira, Tatiana de CA Pinto, Marcos C de Mattos, \\ Leslie C Benchetrit/+
}

Universidade Federal do Rio de Janeiro, Centro de Ciências da Saúde, Instituto de Microbiologia Professor Paulo de Góes, Av. Carlos Chagas Filho 373 Bloco I, 21941-902 Rio de Janeiro, RJ, Brasil

Group B streptococci (GBS) infections occur worldwide. Although serotyping has been used for epidemiologic purposes, this does not accurately characterize enough members of a genetically heterogeneous bacterial population. The aims of this work were to evaluate the genetic diversity of 45 type Ia GBS strains isolated in Brazil by pulsed-field gel electrophoresis as well as to evaluate antimicrobial susceptibility profiles and identify virulence genes. Twenty-four strains were assigned to cluster A. All strains under study contained the hylB and $\mathrm{scpB}$ genes. The bca gene was detected in only 10 strains and none of the streptococci carried the bac gene. Thirty-nine strains were resistant to tetracycline.

Key words: group B streptococci - pulsed-field gel electrophoresis - polymerase chain reaction

Group B streptococci (GBS) are responsible for a large variety of human infections and have been recognized over the last few decades as a leading cause of perinatal disease worldwide (Farley 2001, Weisner et al. 2004). GBS are classified in serotypes (Ia, Ib and IIVIII) that occur in combination with different protein antigens (alpha, beta and rib) (Dmitriev et al. 2001). Currently, serotypes Ia, III and V are the most common in many countries (Duarte et al. 2005, Fluegge et al. 2005, Bergseng et al. 2008, Poyart et al. 2008, von Both et al. 2008).

Pulsed-field gel electrophoresis (PFGE), used to examine GBS strains, is a powerful technique employed for the classification of microorganisms after digestion of the genomic DNA by restriction enzymes (Benson \& Ferrieri 2001, Oliveira et al. 2005, 2006, von Both et al. 2008). Using polymerase chain reaction (PCR), Franken et al. (2001) suggested that the $s c p B$ and $l m b$ genes (encoding c5a peptidase and laminin binding protein) must exist in GBS strains that infect humans. The hylB gene is frequently detected in these strains (Dore et al. 2003). The $b a c$ and $b c a$ genes are present in $23 \%$ and $100 \%$ of type Ia strains, respectively (Maeland et al. 1997, 2000).

The lack of information on Ia Brazilian strains and the availability of DNA techniques led us to investigate the genetic make-up of type Ia GBS strains isolated in distinct regions of Brazil. Additionally, antimicrobial susceptibility was examined to better characterize these isolates.

Financial support: CNPq, FAPERJ, FINEP, MCT, The Thrasher Research Fund

+ Corresponding author: leslie@micro.ufrj.br

Received 24 November 2008

Accepted 26 June 2009

\section{MATERIALS AND METHODS}

Bacterial strains - Forty-five human type Ia GBS strains derived from clinical specimens were obtained in Florianopolis, Santa Catarina $(\mathrm{n}=3)$, a city located in the Southern Region of Brazil, in São Paulo, São Paulo (SP) $(\mathrm{n}=1)$, and in Rio de Janeiro, Rio de Janeiro $(\mathrm{n}=$ 40), in the Southeast Region of the country. The source of one strain was unknown.

Isolates were obtained from 1981-2002 from public health laboratories, gynaecological clinics, hospitalsand universities. The clinical sources included urine $(\mathrm{n}=16)$, oropharynx $(\mathrm{n}=9)$, vagina $(\mathrm{n}=5)$, anus $(\mathrm{n}=2)$, lung $(n=2)$, placenta $(n=1)$, external ear canal $(n=1)$ and perineum $(n=1)$. The sources of eight specimens were unknown. A confirmatory identification of serotypes was carried out again by immunoprecipitation in agarose using sera produced in the research facilities of the authors and $\mathrm{HCl}$ antigenic extracts from the streptococci (Benchetrit et al. 1982).

PFGE - PFGE was performed as previously described (Oliveira et al. 2005). DNA was digested with the SmaI restriction enzyme (Amersham) and submitted to electrophoresis with a program as follows: switch time of $1-30 \mathrm{sec}$ during $23 \mathrm{~h}$, with a $120^{\circ}$ angle, at a temperature of $11.3^{\circ} \mathrm{C}$ and a voltage gradient of $6 \mathrm{~V} / \mathrm{cm}$. The lambda ladder PFGE marker kit (New England Biolabs) was used as a DNA size marker. Gels were stained with ethidium bromide and photographed under UV light. Criteria for analysis of the PFGE patterns were those originally suggested by Tenover et al. (1995) and used in our previous studies (Oliveira et al. 2005, 2006).

$P C R$ - DNA extraction was performed according to Sambrook et al. (1989). DNA fragments of the different GBS genes were amplified at a temperature of $53^{\circ} \mathrm{C}$. PCR-amplified products were run on agarose gels 
and stained with ethidium bromide. The 123-bp lambda ladder kit (Invitrogen) was used as a DNA size marker. A metabolic gene encoding the glucose 6-phosphateisomerase-1 was employed as a positive control in all reactions. Primers were designed by the authors and prepared by Promicro (SP) as follows: 5' -GTACCTTGGTGCAAAAGCAG (forward) and 5' -GAGAAGTTTGCTGATGTAGG (reverse; gene encoding the glucose 6-phosphate-isomerase-1); 5' -CTACAATTCCAGGGAGTGCA (forward) and 5' -ACTTTCTTCCGTCCACTTAG (reverse; $b c a$, encodes alpha protein); 5' -AAGCAACTAGAAGAGGAAGC (forward) and 5' -TTCTGCTCTGGTGTTTTAGG (reverse; $b a c$, encodes beta protein); 5' -CCTGCTAAGACTGCTGATAC (forward) and 5' -CATAAGCATAGTCGTAAGCC (reverse; $s c p B$, encodes C5a peptidase); 5' -CACCAATCCCCACTCTACTA (forward) and 5' -TGTGTCAAACCATCTATCAG (reverse; hylB, encodes hyaluronate lyase). One strain of Streptococcus pyogenes was used as a negative control. Two GBS strains obtained from humans, provided by Dr. L. M. Teixeira (Universidade Federal do Rio de Janeiro), were used as positive controls.

Antimicrobial susceptibility testing - Susceptibility to seven antimicrobial agents was examined by using the single-disk diffusion method and Clinical Laboratory Standards Institute guidelines (CLSI 2006).

\section{RESULTS}

After digestion with SmaI, 34 electrophoretic profiles belonging to eight clusters $(\mathrm{A}-\mathrm{H})$ were observed for the 45 strains (Fig. 1). Twenty-four of the strains belonged to the A cluster (A1-A16 profiles). Five isolates belonged to the B cluster (B1-B3 profiles), three belonged to the $\mathrm{C}$ cluster (C1 and $\mathrm{C} 2$ profiles), nine belonged to the $\mathrm{D}$ cluster (D1-D9 profiles) and each of the remaining four strains belonged to clusters E, F, G and H, respectively. The A1 profile was identified in a strain isolated in 1984 in Florianopolis and 18 years later in Rio de Janeiro. There is a distance of $1,150 \mathrm{~km}$ between these two locations. All strains were $b a c$ negative, $h y l B$ and $s c p B$ positive and 35 were $b c a$ negative. As expected, virulence genes were detected in control strains and the metabolic gene was detected in all reactions (Fig. 2). In addition, all strains were sensitive to penicillin, vancomycin, clindamycin, erythromycin and chloramphenicol. Resistance to tetracycline was seen in 39 isolates and sensitivity was observed for five strains. Forty-three GBS strains were sensitive to rifampin. Intermediate susceptibilities to tetracycline and rifampin were observed for one and two strains, respectively. PFGE and virulence profiles, antimicrobial susceptibilities and the clinical sources of the strains are shown in Table.

\section{DISCUSSION}

Our data describing the molecular epidemiology of 45 Ia GBS strains isolated in Brazil show a remarkable clustering, with 24 isolates in cluster A. It is important to note that the strains were collected over a period of 21 years. There was no specific local or time clustering, as clusters were spread over the 21-year time period and were from all sources. Other researchers found a more enhanced genetic heterogeneity in strains of serotype Ia, which were isolated during a shorter period of time. Skjaervold et al. (2004) identified 10 different electrophoretic profiles among 12 strains isolated in 1999 and

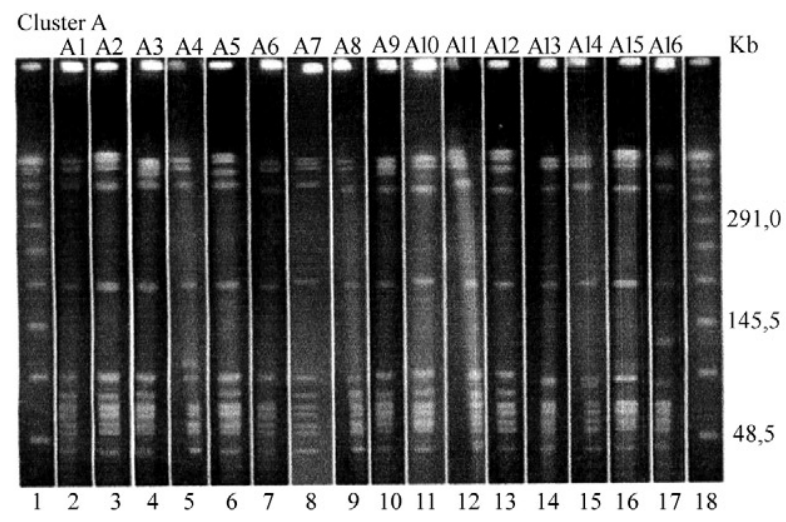

Clusters B-H

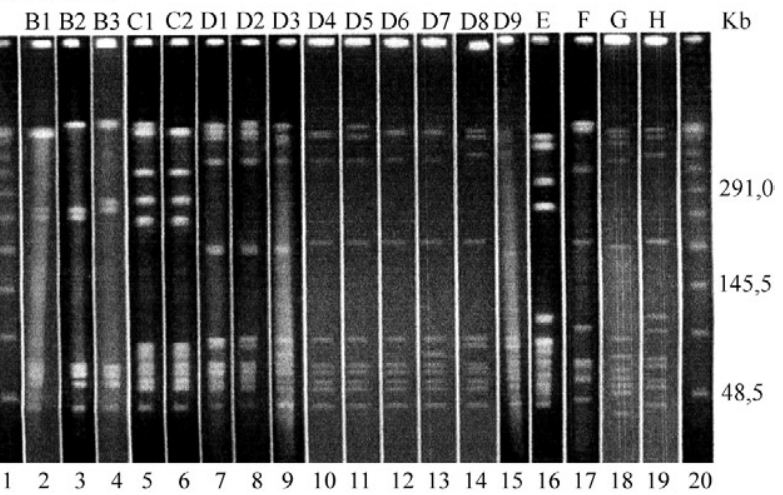

Fig. 1: pulsed-field gel electrophoresis (PFGE) profiles displayed by the Ia group B streptococci strains. Cluster A: Lanes 1,18: lambda ladder PFGE marker; 2-17: A1-A16 profiles. Clusters B-H: Lanes 1, 20: lambda ladder marker; 2-4: $\mathrm{B} 1-\mathrm{B} 3$ profiles; 5,6 : $\mathrm{C} 1$ and $\mathrm{C} 2$ profiles; 7-15: D1-D9 profiles; 16-19: E-H profiles.

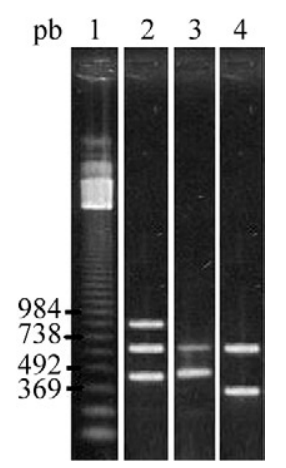

Fig. 2: polymerase chain reaction amplified products of a group B streptococci positive control strain in an agarose gel. 1: 123-bp marker; 2: $s c p B$ (853-bp), housekeeping gene (669-bp) and hylB (444-bp); 3: housekeeping gene and bac (479-bp); 4: housekeeping gene and $b c a(376-\mathrm{bp})$. 
TABLE

Pulsed-field gel electrophoresis (PFGE), virulence profiles, antimicrobial susceptibilities and clinical sources of the Ia group B streptococci strains

\begin{tabular}{|c|c|c|c|c|c|c|c|}
\hline PFGE profile & Strain & Year & Body site & State & $b c a$ & Tetracycline & Rifampin \\
\hline $\mathrm{A} 1$ & 01019 & 2001 & urine & $\mathrm{RJ}$ & + & $\mathrm{R}$ & $\mathrm{S}$ \\
\hline $\mathrm{A} 1$ & 02022 & 2002 & urine & RJ & - & $\mathrm{R}$ & S \\
\hline $\mathrm{A} 1$ & 01015 & 2001 & urine & RJ & - & $\mathrm{R}$ & S \\
\hline $\mathrm{A} 1$ & 84127 & 1984 & ear canal & $\mathrm{SC}$ & + & $\mathrm{R}$ & S \\
\hline A2 & 89311 & 1989 & vagina & RJ & - & $\mathrm{R}$ & S \\
\hline A3 & 85418 & 1985 & pharynx & unknown & - & $\mathrm{R}$ & S \\
\hline A3 & 83154 & 1983 & anus & SC & - & $\mathrm{R}$ & I \\
\hline A4 & 01020 & 2001 & urine & RJ & - & $\mathrm{R}$ & S \\
\hline A4 & 01016 & 2001 & unknown & RJ & - & $\mathrm{R}$ & S \\
\hline A5 & 88606 & 1988 & vagina & $\mathrm{RJ}$ & - & $\mathrm{R}$ & S \\
\hline A5 & 90351 & 1990 & lung & RJ & + & $\mathrm{R}$ & S \\
\hline A6 & 02057 & 1002 & urine & $\mathrm{RJ}$ & + & $\mathrm{R}$ & S \\
\hline A7 & 02029 & 2002 & unknown & RJ & - & $\mathrm{R}$ & S \\
\hline A8 & 01022 & 2001 & urine & RJ & + & $\mathrm{R}$ & $\mathrm{S}$ \\
\hline A9 & 81779 & 1981 & pharynx & SP & - & S & $\mathrm{S}$ \\
\hline $\mathrm{A} 10$ & 90177 & 1990 & vagina & $\mathrm{RJ}$ & - & $\mathrm{R}$ & $\mathrm{S}$ \\
\hline A11 & 01008 & 2001 & unknown & RJ & - & $\mathrm{R}$ & $\mathrm{S}$ \\
\hline A12 & 88686 & 1988 & vagina & RJ & - & $\mathrm{R}$ & $\mathrm{S}$ \\
\hline A13 & 02053 & 2002 & urine & RJ & - & $\mathrm{R}$ & $\mathrm{S}$ \\
\hline A14 & 01009 & 2001 & urine & RJ & - & $\mathrm{R}$ & $\mathrm{S}$ \\
\hline A14 & 01028 & 2001 & vagina & RJ & - & $\mathrm{R}$ & $\mathrm{S}$ \\
\hline A14 & 01029 & 2001 & urine & RJ & - & $\mathrm{R}$ & I \\
\hline A15 & 96027 & 1996 & urine & RJ & - & $\mathrm{R}$ & $\mathrm{S}$ \\
\hline A16 & 02068 & 2002 & unknown & RJ & - & $\mathrm{R}$ & $\mathrm{S}$ \\
\hline B1 & 90218 & 1990 & lung & RJ & - & $\mathrm{S}$ & $\mathrm{S}$ \\
\hline B1 & 90220 & 1990 & perineum & RJ & - & $\mathrm{R}$ & $\mathrm{S}$ \\
\hline B2 & 90222 & 1990 & urine & RJ & - & $\mathrm{R}$ & $\mathrm{S}$ \\
\hline B3 & 85427 & 1985 & pharynx & RJ & - & I & $\mathrm{S}$ \\
\hline B3 & 85685 & 1985 & pharynx & RJ & - & $\mathrm{R}$ & $\mathrm{S}$ \\
\hline $\mathrm{C} 1$ & 91239 & 1991 & pharynx & RJ & + & $\mathrm{R}$ & $\mathrm{S}$ \\
\hline $\mathrm{C} 1$ & 91402 & 1991 & pharynx & RJ & + & $\mathrm{S}$ & $\mathrm{S}$ \\
\hline $\mathrm{C} 2$ & 91199 & 1991 & pharynx & RJ & + & $\mathrm{R}$ & $\mathrm{S}$ \\
\hline D1 & 90096 & 1990 & pharynx & RJ & + & $\mathrm{R}$ & $\mathrm{S}$ \\
\hline $\mathrm{D} 2$ & 02044 & 2002 & urine & RJ & - & $\mathrm{R}$ & S \\
\hline D3 & 90352 & 1990 & placenta & RJ & - & $\mathrm{S}$ & S \\
\hline D4 & 02008 & 2002 & unknown & RJ & - & $\mathrm{R}$ & S \\
\hline D5 & 02016 & 2002 & unknown & RJ & - & $\mathrm{R}$ & S \\
\hline D6 & 02035 & 2002 & unknown & RJ & + & $\mathrm{R}$ & S \\
\hline D7 & 01017 & 2001 & urine & RJ & - & S & S \\
\hline D8 & 02067 & 2002 & urine & RJ & - & $\mathrm{R}$ & S \\
\hline D9 & 02023 & 2002 & urine & RJ & - & $\mathrm{R}$ & $\mathrm{S}$ \\
\hline $\mathrm{E}$ & 89496 & 1989 & pharynx & RJ & - & $\mathrm{R}$ & S \\
\hline $\mathrm{F}$ & 90194 & 1990 & urine & RJ & - & $\mathrm{R}$ & S \\
\hline G & 83093 & 1983 & anus & $\mathrm{SC}$ & - & S & S \\
\hline $\mathrm{H}$ & 96028 & 1996 & unknown & RJ & - & $\mathrm{R}$ & S \\
\hline
\end{tabular}

I: intermediate susceptibility; R: resistant; RJ: Rio de Janeiro; S: sensitive; SC: Santa Catarina; SP: São Paulo. The genes hylB and $s c p B$ were detected in all strains. All isolates were sensitive to penicillin, vancomycin, clindamycin, erythromycin and chloramphenicol. 
2000 in Norway. Savoia et al. (2008) identified seven clusters among 16 strains isolated in 2005 and 2006 in Italy and six of these strains were allocated to one single cluster. Martins et al. (2007), however, reported that 59 of 60 serotype Ia strains isolated between 2000-2004 in Portugal belonged to a single cluster.

There was previously no data about the genetic diversity among serotype Ia Brazilian strains. A similar study was conducted by our research group to analyse strains of type II, III and V isolated in humans in the same geographic areas and period of time (Oliveira et al. 2005). A predominant profile was clearly defined for each of these serotypes but was not identified in our Ia isolates, which instead displayed a slightly higher genetic heterogeneity than others.

The hylB and $s c p B$ genes were detected in all isolates. According to the literature, the $h y l B$ gene is uncommon in bovine GBS strains but is often present in human strains. Some authors even suggest that the presence of the $s c p B$ gene in human isolates is mandatory (Dmitriev et al. 2001, 2004, Franken et al. 2001). However, Duarte et al. (2005) detected $s c p B$ in $97 \%$ of human isolates and Dore et al. (2003) described one hylB negative human strain. Ten of our strains carried the $b c a$ gene. According to the literature, between $30-55 \%$ of serotype Ia GBS human strains carry this $b c a$ gene (Dore et al. 2003, Duarte et al. 2005).

In the present study, none of the 45 streptococci carried the $b a c$ gene. This was also observed in the Brazilian isolates studied by Duarte et al. (2005).

Variable susceptibilities of GBS to erythromycin and clindamycin (from 4-40\%) are described in the literature (Hsueh et al. 2001, Uh et al. 2001, Díaz et al. 2008). Simões et al. (2007) did not detect resistance to erythromycin and clindamycin among Ia isolates collected between 2003-2004 in São Paulo. We also did not detect resistance to these two antibiotics. Duarte et al. (2005) described some resistance to erythromycin (5\%) among Ia strains collected between 2000-2001 in Rio de Janeiro. In the present report, susceptibility to other antimicrobial agents is in agreement with other data in the literature (Hsueh et al. 2001, Uh et al. 2001, Simões et al. 2007).

Our data may suggest a relevant perpetuation and dissemination of cluster A throughout Brazil and may suggest the direction of further studies on this GBS serotype in geographical areas of the Southern Hemisphere, especially in developing countries.

\section{ACKNOWLEDGMENTS}

To Dr. R. R. Facklam (CDC, Atlanta, USA) and P. Ferrieri (University of Minnesota, USA), for help in the typing program.

\section{REFERENCES}

Benchetrit LC, Fracalanzza SEL, Peregrino H, Camelo AA, Sanches LALR 1982. Carriage of Streptococcus agalactiae in women and neonates and distribution of serological types: a study in Brazil. J Clin Microbiol 15: 787-790.

Benson JA, Ferrieri P 2001. Rapid pulsed-field gel electrophoresis method for group B Streptococcus isolates. J Clin Microbiol 39: 3006-3008.
Bergseng H, Rygg M, Bevanger L, Bergh K 2008. Invasive group B Streptococcus (GBS) disease in Norway 1996-2006. Eur J Clin Microbiol Infect Dis 27: 1193-1199.

CLSI - Clinical and Laboratory Standarts Institute 2006. Performance standards for antimicrobial susceptibility testing: 16th informational supplement. M100-S16, vol. 26, CLSI, Wayne, p. 138-140.

Díaz LM, Sánches MJT, Martín, JA 2008. Prevalence and mechanisms of erythromycin and clindamycin resistance in clinical isolates of $\beta$-haemolytic streptococci of Lancefield groups A, B, C and $\mathrm{G}$ in Seville, Spain. Clin Microbiol Infect 14: 85-87.

Dmitriev A, Hu YY, Shen AD, Surovov A, Yang YH 2001. Chromosomal analysis of group B streptococcal clinical strains: $b a c$ gene-positive strains are genetically homogeneous. FEMS Microbiol Lett 208: 93-98.

Dmitriev A, Suvorov A, Shen AD, Yang YH 2004. Clinical diagnosis of group B streptococci by $s c p$ gene based PCR. Indian J Med Res 119: 233-236.

Dore N, Bennett D, Kaliszer M, Cafferkey M, Smyth CJ 2003. Molecular epidemiology of group B streptococci in Ireland: associations between serotype, invasive status and presence of genes encoding putative virulence factors. Epidemiol Infect 131: 823-833.

Duarte RS, Bellei BC, Miranda OP, Brito MAVP, Teixeira LM 2005. Distribution of antimicrobial resistance and virulence-related genes among Brazilian group B streptococci recovered from bovine and human sources. Antimicrobial Agents Chemother 49: 97-103.

Farley MM 2001. Group B streptococcal disease in nonpregnant adults. Clin Infect Dis 43: 556-561.

Fluegge K, Supper S, Siedler A, Berner R 2005. Serotype distribution of invasive group B streptococcal isolates in infants: results from a nationwide active laboratory surveillance study over 2 years in Germany. Clin Infect Dis 40: 760-763.

Franken C, Haase G, Brandt C, Weber-Heynemann J, Martin S, Lämmler C, Podbielski A, Lütticken R, Spellerberg B 2001. Horizontal gene transfer and host specificity of beta-haemolytic streptococci: the role of a putative composite transposon containing scpB and lmb. Mol Microbiol 41: 925-935.

Hsueh P, Teng L, Lee L, Ho S, Yang P, Luh K 2001. High incidence of erythromycin resistance among clinical isolates of Streptococcus agalactiae in Taiwan. Antimicrob Agents Chemother 45: 3205-3208.

Maeland JA, Brakstad OG, Bevanger L, Krokstad S 2000. Distribution and expression of $b c a$, the gene encoding the $\mathrm{c}$ alpha protein, by Streptococcus agalactiae. J Med Microbiol 49: 193-198.

Maeland JA, Brakstad OG, Bevanger L, Kvam A I 1997. Streptococcus agalactiae beta gene and gene product variations. J Med Microbiol 46: 999-1005.

Martins ER, Pessanha MA, Ramirez M, Melo-Cristino J, Portuguese Group for the Study of Streptococcal Infections 2007. Analysis of group B streptococcal isolates from infants and pregnant women in Portugal revealing two lineages with enhanced invasiveness. J Clin Microbiol 45: 3224-3229.

Oliveira ICM, de Mattos MC, Areal MFT, Ferreira-Carvalho BT, Figueiredo AMS, Benchetrit LC 2005. Pulsed-field gel electrophoresis oh human group B streptococci isolated in Brazil. J Chemother 17: 258-263.

Oliveira ICM, de Mattos MC, Pinto TCA, Ferreira-Carvalho BT, Benchetrit LC, Whiting AA, Bohnsack JF, Figueiredo MAS 2006. Genetic relatedness between group B streptococci originating from bovine mastitis and a human group B Streptococcus type $\mathrm{V}$ cluster displaying an identical pulsed-field gel electrophoresis pattern. Clin Microbiol Infect 12: 887-893. 
Poyart C, Réglier-Poupet H, Tazi A, Billoët A, Dmytruk N, Bidet P, Bingen E, Raymond J, trieu-Cuot P 2008. Invasive group B streptococcal infections in infants, France. Emerg Infect Dis 14: 1647-1649.

Sambrook J, Fritsh EF, Maniatis T 1989. Molecular cloning: a laboratory manual, Cold Spring Harbor Laboratory Press, New York, $2.344 \mathrm{pp}$.

Savoia D, Gottimer C, Crocilla C, Zucca M 2008. Streptococcus agalactiae in pregnant women: phenotypic and genotypic characters. $J$ Infect 56: 120-125.

Simões JA, Alves VMN, Fracalanzza SEL, Camargo RPS, Mathias L, Milanez HMBP, Brolazo EM 2007. Phenotypical characteristics of group B streptococcus in parturients. Braz J Infect Dis 11: $261-266$

Skjaervold NK, Bergh K, Bevanger L 2004. Distribution of PFGE types of invasive Norwegian group B streptococci in relation to serotypes. Indian J Med Res 119: 201-204.

Tenover FC, Arbeit RD, Goering RV, Mickelsen PA, Murray BE, Persing DH, Swaminathan B 1995. Interpreting chromosomal DNA restriction patterns produced by pulsed-field gel electrophoresis: criteria for bacterial strain typing. J Clin Microbiol 33: 2233-2239.

Uh Y, Jang IH, Yoon KJ, Song W 2001. Emerging erythromycin resistance among group B streptococci in Korea. Eur J Clin Microbiol Infect Dis 20: 52-54.

von Both U, John A, Fluegge K, Siedler A, Berner R 2008. Molecular epidemiology of invasive neonatal Streptococcus agalactiae isolates in Germany. Pediatr Infect Dis J 27: 903-906.

Weisner A, Johnson A, Lamegni T, Arnold E, Warner M, Heath PT, Efstratiou A 2004. Characterization of group B streptococci recovered from infants with invasive disease in England and Wales. Clin Infect Dis 43: 1203-1208. 